ty historyczne. Obie warstwy mogą istnieć niezależnym życiem, ale tylko zespolone w jedność pozwalają wnikliwemu obserwatorowi i czytelnikowi wypracować sobie obiektywny ogląd na rzeczywistość, która towarzyszyła ludności zamieszkującej Kresy Wschodnie II Rzeczypospolitej czy Ziemie Zachodnie Samoistnej Ukrainy.

\title{
Literatura
}

Isakowicz-Zaleski T., Ekspatriacja, [w:] Przemilczane ludobójstwo na Kresach, Kraków 2008.

Kresten K., Repatriacja ludności polskiej po II wojnie światowej, Warszawa 1974.

Kubis K. B., Losy Polaków wysiedlonych z Kresów Wschodnich II RP. Przyjazd na ziemie zachodnie (1944-1945). W zapisach wspomnieniowych 40 lat później, Opole 2011.

Kubis K. B., Poznawcze i kształcace walory literatury dokumentu osobistego, Opole 2007.

Siemaszko E. W., Ludobójstwo dokonane przez nacjonalistów ukraińskich na ludności polskiej Wotynia 1939-1945, Warszawa 2000.

Henryk Andrzej Kretek (doktorant Uniwersytetu Opolskiego)

Szczecin - źródła wiedzy o historii miasta. Od archeologii do czasów najnowszych. Pierwsza Konferencja Edukacyjna, Szczecin 9 XII 2008 r., red. Katarzyna Rembacka, Szczecin 2009, ss. 118

Szczecin - historię tworza ludzie. Druga Konferencja Edukacyjna, Szczecin 11 XII 2009 r., red. Katarzyna Rembacka, Szczecin 2010, ss. 239

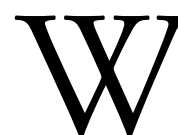

grudniu 2008 roku zapoczątkowano cykl konferencji edukacyjnych poświęconych różnorodnej tematyce związanej z historią Szczecina oraz Pomorza Zachodniego. Ich organizatorami są: szczeciński oddział Instytutu Pamięci Narodowej, Urząd Miasta w Szczecinie, Kuratorium Oświaty w Szczecinie oraz Polskie Radio Szczecin. Konferencje edukacyjne dla nauczycieli odbywa- 
ją się w siedzibie szczecińskiego IPN. Każda z nich została opatrzona materiałami pokonferencyjnymi w postaci książek, za których redakcję odpowiadała Katarzyna Rembacka (IPN Szczecin). Wartość każdej z publikacji podnosi naukowa recenzja szczecińskich profesorów historii oraz fakt, że autorzy reprezentują czołowe placówki naukowe i kulturalne Szczecina. Warto wspomnieć, że każdy z uczestników konferencji nieodpłatnie otrzymał po egzemplarzu wydanej książki. Publikacje pokonferencyjne trafiły również do wszystkich bibliotek szczecińskich szkół.

Pierwszą z konferencji, która odbyła się 9 grudnia 2008 r., poświęcono źródłom wiedzy o historii Szczecina oraz ich wykorzystaniu w edukacji regionalnej. Jej pokłosiem była książka pt. Szczecin - źródła wiedzy o historii miasta. Od archeologii do czasów najnowszych. Pierwsza Konferencja Edukacyjna, Szczecin 9 XII 2008 r., zawierająca referaty wraz ze wskazówkami metodycznymi dla nauczycieli. Jej recenzji naukowej dokonał prof. Radosław Gaziński (Uniwersytet Szczeciński). Do książki załączono płytę CD z kopiami najważniejszych źródeł, które można wykorzystać podczas lekcji.

Przystępną gawędę o meandrach archeologii Szczecina czytelnik zawdzięcza Przemysławowi Krajewskiemu (Uniwersytet Szczeciński) w referacie Przegląd źródet archeologicznych z terenu Szczecina. Autor skupił się na obiektach ze szczecińskich muzeów, pozyskanych m.in. podczas likwidacji szczecińskiej twierdzy. W referacie także zostały omówione prace służb archeologicznych, motywy ich pracy oraz wyniki działalności. Źródła archeologiczne służą przede wszystkich poznaniu życia codziennego w Szczecinie. Podsumowując podano najbardziej dostępną literaturę, którą mogą wykorzystać nauczyciele i uczniowie.

W edukacji historycznej dużo uwagi poświęcono umiejętnościom odczytywania źródeł ikonograficznych. Naprzeciw temu wyzwaniu wyszła Ewa Gwiazdowska (Muzeum Narodowe w Szczecinie) w referacie Plan i panorama Szczecina w okresie nowożytnym jako źródta ikonograficzne wiedzy o mieście. Prócz tego, że Autorka dała podstawowe informacje z terminologii ikonograficznej, podsunęła również szereg wskazówek metodycznych, wymieniła również najbardziej typowe plany i widoki Szczecina. Dała także spis najlepszych źródeł wspomnianych wizerunków miasta. Nauczycielowi i uczniom Autorka dostarczyła gotowe propozycje ćwiczeń.

Interesujący przykład analizy źródła ikonograficznego zaproponował Radosław Skrycki (Uniwersytet Szczeciński) w referacie O wykorzystaniu dawnych map $w$ nauczaniu historii. Autor dokonał próby interpretacji alegorii z osiemnastowiecznej mapy Pomorza Zachodniego J. B. Homanna. Radosław Skrycki podjął się trudnego zadania wykraczającego poza umiejętności uczniów. Szkoda, że nie podał przykładowej literatury mogącej pomóc w odczytaniu szeregu symboli. Ponadto zabrakło w artykule przykładów analizy treści kartograficznej, wszak pisze tu o mapach. 
Wojciech Łopuch (Książnica Pomorska w Szczecinie) na początku referatu Architektura wielkomiejskiego Szczecina (XIX/XX w.), źródło historyczne do dziejów miasta zadał pytanie problemowe, które może być kwintesencją jego opracowania. Autor zastanawia się, czy miasto, jego układ i architektura mogą być przydatnym i atrakcyjnym źródłem historycznym? Dodatkowo omówił charakterystyczne rozplanowanie Szczecina nawiązujące do rozwiązań Paryża oraz budowle-symbole dla okresu Drugiej Rzeszy Niemieckiej. Poza tym Autor dokonał próby zafascynowania młodego odbiorcy wspaniałą architekturą wielkiego miasta.

Uczeń podczas wielu sprawdzianów i egzaminów spotka się z analizą źródeł pisanych. W interesujący sposób podczas ćwiczeń można wykorzystać źródła poświęcone dziejom lokalnym jakim są gazety. Ciekawą propozycję przygotowała Katarzyna Rembacka (IPN Szczecin) w referacie pt. „Polityczne przetomy” w szczecińskiej prasie codziennej, skupiając się na trzech charakterystycznych wydarzeniach z historii PRL. Czytelnik otrzymał również szereg wskazówek metodycznych jak i metodologicznych. Autorka omówiła również trudności na jakie może natrafić i nauczyciel i uczeń czytając teksty z okresu Polski Ludowej, przepełnione socjalistyczną retoryką. Dlatego ważną rolę odgrywa tu krytyczna analiza tekstu propagandowego.

Propozycję krytyki wewnętrznej fotografii zaproponował Paweł Miedziński (IPN Szczecin) w referacie pt. Ikony Szczecina - fotografia jako źródto do badań nad historią miasta. Szczególnie skupił się na wydarzeniach Grudnia 1970 r. Zaznaczył, że fotografia nie jest tylko ilustracją, można ją porównać do tekstu. Autor zwrócił uwagę na to, że aby podjąć analizę fotografii należy uwzględnić kontekst wydarzeń w jakich powstawała. Podczas interpretacji fotografii bardzo ważne jest: kto je wykonał, w jakim celu, dla kogo, w jakiej sytuacji, czy fotografujący potrafił wykonywać zdjęcia? Odpowiedź na powyższe pytania ma pomóc w odczytywaniu zdjęć z wydarzeń szczecińskiego Grudnia 1970 r.

Materiał dydaktyczny zaproponowała Małgorzata Machałek (PTH o. Szczecin) w referacie pt. Film fabularny „Skarga” w reż. Jerzego Wójcika jako źródto wiedzy o dramacie szczecińskiego Grudnia '70. Dzięki jej opracowaniu nauczyciel może wykorzystać podczas zajęć film fabularny, omawiający wydarzenia Grudnia '70, stosując aktywne metody nauczania - kartę pracy oraz metaplan.

Dość nietypowe źródło historyczne do dziejów Szczecina omówił Paweł Szulc (IPN Szczecin) w referacie pt. Fonoteka Polskiego Radia Szczecin jako źródto wiedzy o powojennej historii Szczecina. Tematem jego opracowania są audycje Polskiego Radia Szczecin. Podobnie jak w przypadku prasy oraz fotografii, podczas analizy materiału dźwiękowego bardzo istotny jest kontekst polityczno-społeczny. Autor dał ciekawy rys historyczny rozgłośni oraz charakterystykę zasobu archiwalnego. $\mathrm{Na}$ kilkunastu stronach wymienił wybrane audycje z fonoteki Polskiego Radia Szcze- 
cin. Ubolewać należy nad tym, że Autor ani nie dał żadnej propozycji metodycznej do wykorzystania jej podczas zajęć, ani też na płycie CD nie zamieszczono ani jednej przykładowej audycji.

Referat kończący omawianą publikację autorstwa Arkadiusza Bisa (sedina.pl) pt. sedina.pl - Portal Miłośników Dawnego Szczecina poświęcony został portalowi internetowemu który jest niewyczerpanym źródłem wiadomości o dawnym Szczecinie. Zawiera on ok. 2300 artykułów dotyczących historii miasta, ok. 20 tys. fotografii oraz forum dyskusyjne. W artykule omówiono ideę portalu oraz poddano szczegółowej charakterystyce jego zawartość. Portal sedina.pl jest typowym przykładem narzędzia w znaczny sposób popularyzującego lokalną historię w bardzo nowoczesny i przystępny sposób.

Publikacja Szczecin - źródta wiedzy o historii miasta (...) dała początek cyklowi konferencji oraz publikacji. Kontynuację tego pomysłu odzwierciedla kolejna książka warta omówienia: Szczecin - historię tworzą ludzie. Druga konferencja Edukacyjna, Szczecin 11 XII 2009 r. (red. K. Rembacka). Nad jej wysokim poziomem merytorycznym czuwał prof. Edward Włodarczyk (Uniwersytet Szczeciński).

Celem organizatorów drugiej konferencji edukacyjnej, której materiały zostaną poddane charakterystyce poniżej, było omówienie wybranych postaci mających wpływ na rozwój Szczecina. Starano się podczas niej przedstawić osoby, które żyły w Szczecinie, w nim tworzyły i reprezentowały różne epoki.

Każdy referat został opatrzony portretem opisywanej osoby, co podnosi wartość publikacji.

Szczególną uwagę chciałbym zwrócić na najbardziej wartościowy z punktu widzenia nauczyciela referat autorstwa Pawła Migdalskiego (Uniwersytet Szczeciński) pt. Szczecińskie misje biskupa [bamberskiego] Ottona oraz jego kult w szkolnej edukacji regionalnej. Autor przedstawił bohatera swojego referatu z dwóch różnych punktów widzenia. Omawiając biskupa Ottona z Bambergu, przede wszystkim skupił się na jego misji chrystianizacyjnej. Następnie zamieścił wiele uwag o charakterze dydaktycznym, m.in. mamy tu rozważania na temat miejsca edukacji regionalnej w kształceniu humanistycznym w polskiej szkole oraz krytykę niektórych programów edukacji regionalnej na Pomorzu Zachodnim. Paweł Migdalski zaproponował nauczycielom historii wykorzystanie żywota św. Ottona jako źródła historycznego do czterech trafnie dobranych tematów lekcyjnych wypływających z podstawy programowej do przedmiotu historia. Do tego tekstu przygotował szereg ćwiczeń źródłoznawczych poświęconych szeroko pojętej tematyce pomorskiej oraz kompletne wskazówki metodyczne. Na szczególną uwagę zasługują przykładowe tematy zadań praktycznych, które można wykorzystać do realizacji projektów. Omawiając kwestie kultu św. Ottona w Szczecinie i na Pomorzu Zachodnim również mamy gotowe propozycje projektów, np. wycieczki śladami św. Ottona, portfolio - Kultśw. Ottona 
a Szczecin nieistniejący itp. Pod względem oprawy metodycznej jest to najcenniejszy referat, który powinien być wykorzystany podczas zajęć w szczecińskiej lub zachodniopomorskiej szkole.

Edward Rymar w referacie Boguslaus Decimus Magnus - wielki i dziś dał cenny materiał do charakterystyki władcy. W tekście mamy fragmenty Pomeranii kroniki pomorskiej z XVI wieku. Ponadto Autor swój referat opatrzył „smaczkami z książęcej alkowy”. Mamy tu ciekawy przykład sylwetki władcy renesansowego. Ponadto omawiając opis podróży księcia Bogusława X do Ziemi Świętej znajdziemy tu opisy dworu papieskiego i życia zagranicznych gości podczas podróży. Edward Rymar dał czytelnikowi rzetelne opracowanie naukowe pełne faktów z życia księcia. Nauczyciel z tego referatu może zaczerpnąć wiele wątków, które mógłby wykorzystać podczas lekcji: polityka międzynarodowa, polityka wewnętrzna wobec Kościoła pomorskiego i miast, władca renesansowy, życie dworskie w Europie, podróże zagraniczne. Jednak brakiem jest tu pominięcie oprawy metodycznej którą można by wykorzystać podczas zajęć.

Rzetelną biografię mecenasa nauki i sztuki dał Radosław Gaziński (Uniwersytet Szczeciński) w referacie Książe Filip II w świetle dziennika Filipa Hainhofera. Kolekcjoner, mitośnik sztuki i ksiażek.

Biografię połączoną z analizą źródeł kartograficznych przedstawił Radosław Skrycki (Uniwersytet Szczeciński) w referacie Gerhard Cornelius von Walrave architekt szczecinskiej twierdzy. Wczytując się w referat uzyskujemy cenne informacje dotyczące interesującego materiału kartograficznego, który mógłby posłużyć jako ilustracja lub nawet źródło do wykorzystania podczas zajęć historii. Na szczególną uwagę zasługuje podanie podstawowej literatury zawierającej opracowania dotyczące twierdzy w Szczecinie oraz źródła ilustracji. Referat został opatrzony pięcioma dość dobrymi reprodukcjami planów. Jednak brakuje tu opracowania metodycznego choć jednego z nich.

Referat Ewy Gwiazdowskiej (Muzeum Narodowe w Szczecinie), pt. August Ludwig Most najwybitniejszy szczecinski malarz biedermeieru, może stać się dobrym materiałem do wykorzystania podczas lekcji nie tylko plastyki. Most przede wszystkim jest znany z twórczości o charakterze etnograficznym, ukazującym życie codzienne na Pomorzu Zachodnim w XIX wieku. Autorka, stosując wartką narrację, przedstawiła swojego bohatera na tle twórczości innych artystów epoki. Referat wieńczy bogaty materiał dydaktyczny z propozycją lekcji muzealnych w placówkach Szczecina. Ponadto mamy ćwiczenia dla uczniów. Oprócz wskazówek metodycznych Autorka dała interesującą pomoc dla nauczyciela - opisy obrazów Mosta, przygotowane przez specjalistę - historyka sztuki. Cennym jest podanie lokalizacji oryginałów omawianych dzieł oraz zestawienie podstawowej literatury w języku polskim. Opracowanie Ewy Gwiazdowskiej ma charakter uniwersalny. Metoda jaką 
przyjęła Autorka (podobnie jak w poprzedniej publikacji) może być dobrym wzorem metodologicznym dla kolejnych referatów podczas przyszłych konferencji.

Tomasz Ślepowroński (Uniwersytet Szczeciński) w referacie Erich Wiesner jeden z ostatnich niemieckich burmistrzów Szczecina na tle biografii odkrywa przed czytelnikiem interesujące epizody z dziejów Szczecina. Przede wszystkim ukazał rywalizację polsko-niemiecką o przynależność polityczną Szczecina po II wojnie światowej. Autor na bazie stosunków polsko-niemiecko-radzieckich pozostawia otwarty problem, który może stać się przyczynkiem dyskusji wśród uczniów.

Katarzyna Rembacka (IPN Szczecin) w referacie Wspomnień czar, wspomnień czas. Uwagi o szczecińskim okresie działalności Leonarda Borkowicza omówiła pierwszego polskiego wojewodę zachodniopomorskiego. Autorka odesłała czytelników do zapoznania się z cennymi zapiskami Borkowicza, które mogłyby stać się wdzięcznym tematem dla uczniowskiego projektu.

Pierwsze dni polskiego szkolnictwa w Szczecinie na tle biografii Janiny Szczerskiej omówiła Małgorzata Machałek (Muzeum Narodowe w Szczecinie) w referacie Janina Szczerska - nauczyciel i wychowawca w trudnych czasach. Ponadto Autorka dała propozycję opracowanego tematu Szkoła na Pomorzu Zachodnim w latach pionierskich. Cenną pomocą są tu załączniki, na które składa się osiem wypisów źródłowych.

Dwa ostatnie referaty: Pawła Miedzińskiego (IPN Szczecin) pt. Edmund Batuka losy robotniczej legendy oraz Eryka Krasuckiego (Uniwersytet Szczeciński) Marian Jurczyk w poszukiwaniu (straconej ?) biografii (1970-1989) omawiają losy szczecińskich opozycjonistów z okresu Polski Ludowej.

Jeden z referatów: Dawna biblioteka szkolna i jej pracownicy... Janiny Kosman (Archiwum Państwowe Szczecin) nie wpisuje się w tematykę omawianej książki, nie jest bowiem biografią, lecz bardziej ukazuje historię edukacji w Szczecinie. Omówiono w nim wpływ biblioteki szkolnej na życie społeczne.

Obydwie powyżej scharakteryzowane publikacje zasługują na wysoką ocenę. Otworzyły one cykl konferencji edukacyjnych oraz materiałów, które dają nauczycielom-regionalistom szereg propozycji do wykorzystania w codziennej pracy w szkole. Część z nich doskonale wpisuje się w tematykę wynikającą z obecnie obowiązującej podstawy programowej, część z nich może być wykorzystana podczas zajęć pozalekcyjnych lub jako propozycje projektów uczniowskich. Wiele artykułów zamieszczonych w recenzowanych książkach jest o tyle wartościowych, że dają one gotowy materiał do wykorzystania przez nauczyciela. Część z nich odsyła do cennych publikacji zawierających reprodukcje źródeł ikonograficznych lub źródeł pisanych. Pomimo że nie wszystkie zamieszczone w niej artykuły dają propozycje metodyczne, to przede wszystkim popularyzują zagadnienia nieznane lub niezauważane na co dzień w nauczaniu historii. Ponadto cennym aspektem wielu refera- 
tów jest odwoływanie się do publikacji naukowych lub popularnych, gdzie można uzyskać szerszą wiedzę na ów temat, lub zdobyć więcej źródeł do wykorzystania na zajęciach.

W dniu 10 grudnia 2010 r. odbyła się Trzecia Konferencja Edukacyjna pt. „Szczecin i jego miejsca”, w październiku b.r. ukazała się publikacja pokonferencyjna. Natomiast 9 grudnia 2011 r. odbyła się Czwarta Konferencja Edukacyjna „Szczecin - codzienność miasta i jego mieszkańców”, z której publikację materiałów zaplanowano na jesień 2012 r.

Jarostaw Łuczyński (Toruń)

\section{Glosarium wyrazów i zwrotów ze średniowiecznych źródet pruskich, oprac. K. Kopiński, J. Tandecki, Toruń 2011, ss. 416}

$\mathrm{P}$ rzedstawiona publikacja została opracowana przez pracowników Zakładu Źródłoznawstwa i Edytorstwa Instytutu Historii i Archiwistyki Wydziału Nauk Historycznych Uniwersytetu Mikołaja Kopernika w Toruniu - Janusza Tandeckiego oraz Krzysztofa Kopińskiego. W obszarze zainteresowań badawczych Janusza Tandeckiego obok edycji źródeł historycznych znajdują się także zagadnienia związane z dyplomatyką i archiwistyką, historia miast oraz dzieje państwa krzyżackiego w Prusach. Krzysztof Kopiński zajmuje się komputerowymi metodami w edytorstwie źródeł, komputeryzacją oraz systemami informacyjnymi polskich archiwów, a także historią Torunia. Nie jest to pierwsze wspólnie przygotowane wydawnictwo, bowiem autorzy mają już za sobą kilka razem opracowanych edycji źródeł historycznych $^{1}$. Warto podkreślić, że obaj badacze nie są germanistami. Nie trzeba jednak podawać w wątpliwość ich kompetencji do podjętego przedsięwzięcia. Należałoby raczej docenić pomysł i wkład pracy wniesionej w jego sfinalizowanie.

${ }^{1}$ Księga tawnicza starego miasta Torunia (1456-1479), wyd. K. Kopiński, J. Tandecki, Toruń 2007; Ksiegga kamlarii miasta Torunia z lat 1453-1495 = Kämmereibuch der Stadt Thorn von 1453 bis 1495, wyd. K. Kopiński, K. Mikulski, J. Tandecki, Toruń 2007; Quellen kirchlicher Provenienz neue Editionsvorhaben und aktuelle EDV-Projekte, Editionswissenschaftliches Kolloquium 2011, hrsg. von H. Flachenecker und J. Tandecki, unter Mitarb. von K. Kopiński, Toruń 2011. 